\title{
Coal Resource Assessments in the Northern and Central Appalachian Coal Region
}

\section{Introduction}

Coal has been mined actively and extensively in the Appalachian coal region (fig. 1) since the mid-1800's. In some areas, production from major coal beds began to decline as early as 1907 . Nevertheless, 40 percent of U.S. coal production still comes from the States of Ohio, Pennsylvania, West Virginia, Virginia, Maryland, eastern Kentucky, and Tennessee. These States contain six of the top coal-producing beds in the Appalachian basin-the Pittsburgh, Upper Freeport, and Lower Kittanning coal beds in the northern Appalachian coal region and the Pond Creek, Fire Clay, and Pocahontas No. 3 in the central Appalachian coal region.

Even though many of these coal beds are still being mined at top production levels, information on the distribution and quality of remaining coal in the northern and central Appalachians is obsolete; in some areas, the last detailed maps of the coal beds were made nearly 90 years ago. To respond to present needs, including clean air standards and growing concern about potential hazardous pollutants in coal, we need up-to-date information on the amount of remaining coal, its quality, and its distribution.

The U.S. Geological Survey (USGS) National Coal Resource Assessment is assessing the Nation's top-producing coal beds and zones. The program, to be completed in 2000 , will provide digital assessments of the quality and quantity of the top producing coals throughout the United States. In the northern and central Appalachians, the focus is on the six coal beds mentioned above. The assessment is being achieved through close partnerships with the State Geological Surveys of Ohio, Pennsylvania, West Virginia, Virginia, Maryland,

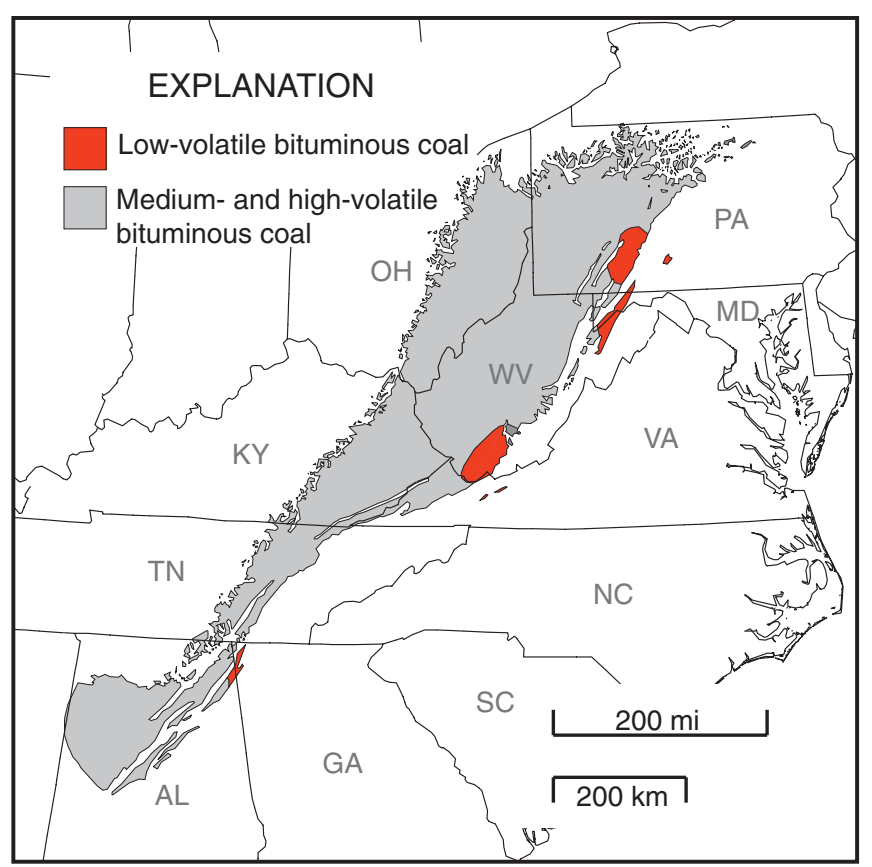

Figure 1. The Appalachian basin coal region. The USGS assessment is focused in the northern and central parts of the Appalachian coal region (Kentucky, West Virginia, Virginia, Maryland, Pennsylvania, and Ohio) because about 93 percent of Appalachian coal is produced here.
Kentucky, and Tennessee. These States enter new data and data from published records that reside in the State archives into the National Coal Resource Data System (NCRDS). State data form the foundation of the assessment in the Appalachian coal region, and State participation is funded through the USGS State Cooperative project.

\section{Assessment Products}

Earlier in the century, it was sufficient to know the location of coal beds, their thickness, rank, coking characteristics, and how they could best be mined. Today, a much broader range of information is necessary to evaluate coal resources, including data on sulfur content, ash yield, and potential hazardous pollutants. The National Coal Resource Assessment is designed to compile and integrate the available information, store it in a form that is easily accessible and readily updated, and summarize it in a variety of useful products based on geographical information systems (GIS) (see figs. 2-7). The national assessment thus provides both an up-to- date view of the Nation's coal resources and an ongoing archive of coal information available for public use.

The primary products of the assessment of the northern and central Appalachians will be digital databases of detailed information on the six major producing coal beds. This information will be made available on a CD-ROM containing stratigraphic and geochemical databases of all nonproprietary information used in the assessment. In addition to basic data for each coal bed, the CD-ROM will provide estimates of original and remaining resources and a variety of maps, cross sections, and graphs (see the section entitled "The Pittsburgh Coal Bed-An Example Assessment").

(Continued on back page) 


\section{The Pittsburgh Coal Bed- An Example Assessment}

The Pittsburgh coal bed (fig. 2), the top producer in the northern Appalachian region and the second largest producer in the Nation, is the first of the six coal beds in the northern and central Appalachian basin coal region to undergo full digital assessment. We are presenting data for the Pittsburgh coal bed as an example of the type of information that is being compiled during the assessment of coal resources in the Appalachian basin.

The stratigraphic database contains more than 5,000 descriptions from drill cores, mine locations, and outcrops, with an additional 2,000 records that contain data on coal elevation. The geochemical database consists of about 3,400 analyses of ash yield, sulfur content, and calorific value and about 160 analyses of selected major, minor, and trace elements. In addition, more than 100 paper maps at scales ranging from $1: 24,000$ to $1: 250,000$ were digitized to create a single GIS coverage of the extent of the coal bed.

For each of the subject coal beds, a number of maps will summarize the information contained in the databases. The CD-ROM will provide maps of total extent and mined area (fig. 2), structure contour (or coal bed elevation) (fig. 3), overburden thickness (the material that

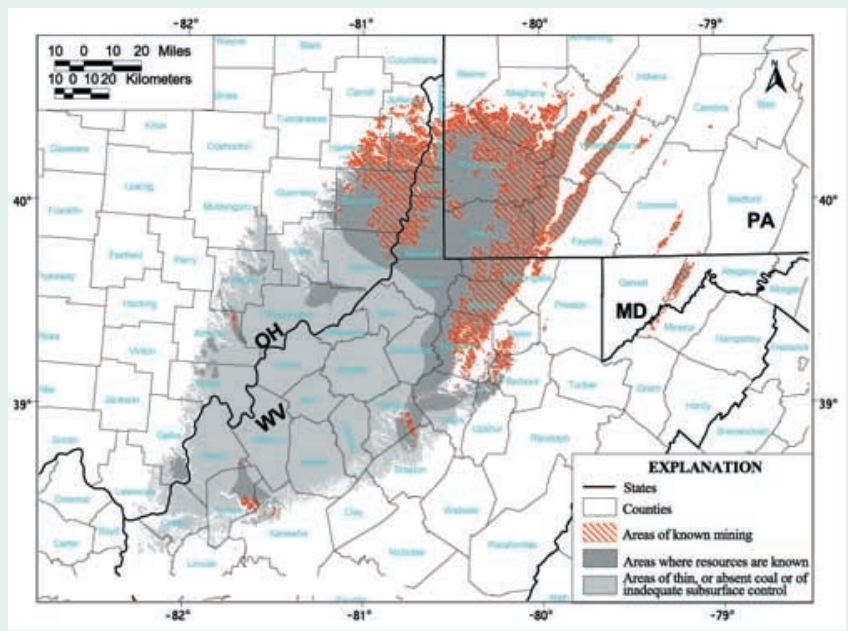

Figure 2. Extent of the Pittsburgh coal bed and its stratigraphically equivalent horizon (which is represented by thin or absent coal or insufficient data), areas of known mining, and areas that contain resources that are not presently mined. From Ruppert, Tewalt, and Bragg, 1997.

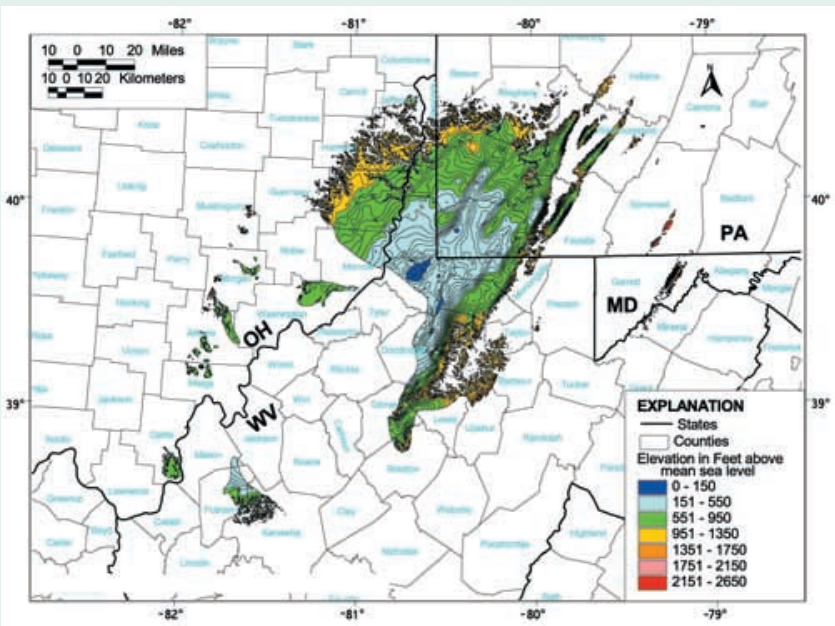

Figure 3. Top of the Pittsburgh coal bed. The structure contour interval is 50 feet. From Tewalt, Ruppert, Bragg, Carlton, Brezinski, Yarnell, and Wallack, 1997, sheet 1.

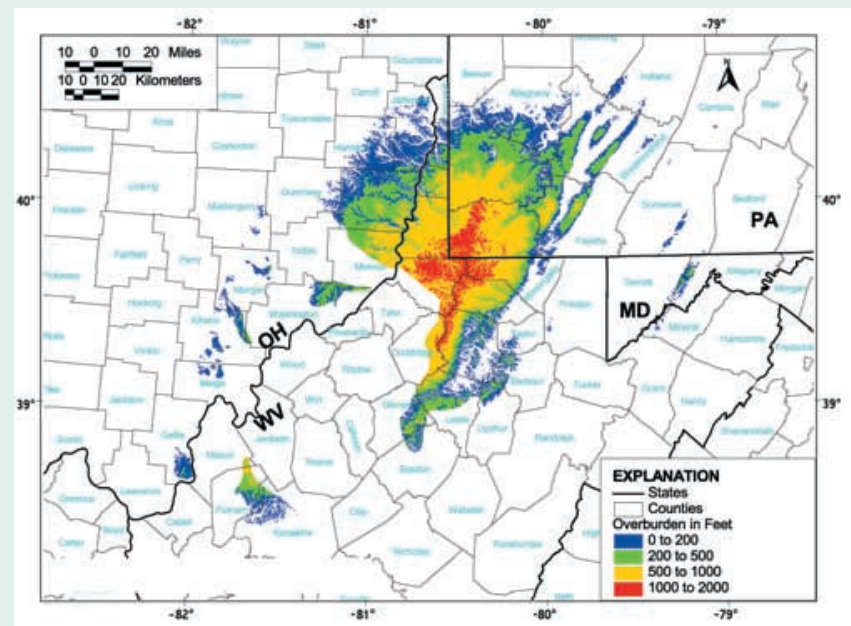

Figure 4. Overburden thickness or the thickness of the rock and soil that lie above the Pittsburgh coal bed. The thickness was derived by subtracting the elevation of the Pittsburgh coal bed from digital models that represent surface elevation. Overburden thickness categories are defined by mining practices and USGS coal resource methodology. From Tewalt, Ruppert, Bragg, Carlton, Brezinski, Yarnell, and Wallack, 1997, sheet 2.

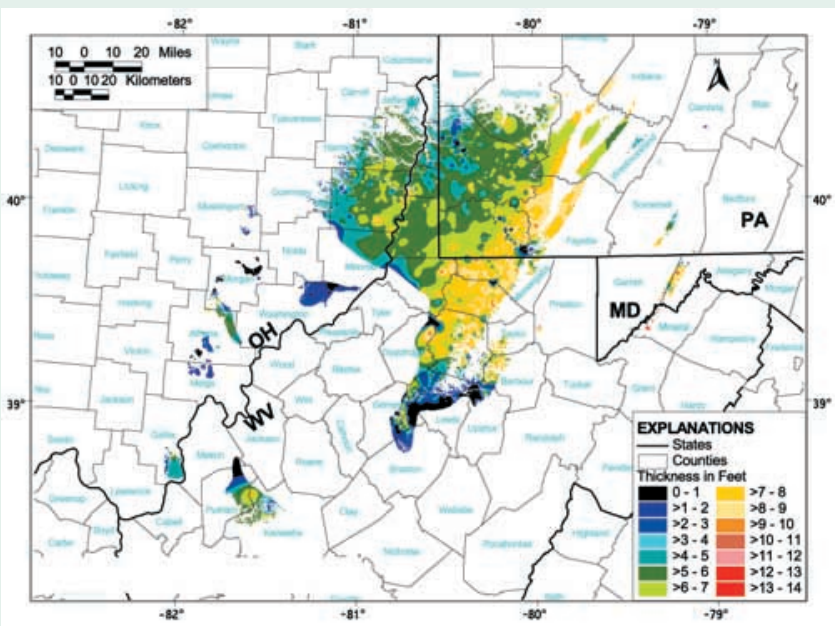

Figure 5. Thickness of the Pittsburgh coal bed, as represented by isopach lines or thickness contours, generalized to remove local variations. Thickness contours are presented at 2-foot intervals. From Tewalt, Ruppert, Bragg, Carlton, Brezinski, and Wallack, 1997. 
overlies the coal) (fig. 4), and coal bed thickness (fig. 5). Table 1 presents mean ash yield, sulfur content, and calorific value (on an as-received basis) by State. In addition to these maps and charts, the CD-ROM will provide summary geologic cross sections, stratigraphic columns (fig. 6), and point-and-click maps that will allow the user to easily retrieve data for specific map localities. Resource information will also be available by State and county. In addition to the CDROM, the material compiled for each of the six major producing beds will be available on the World Wide Web.

The Pittsburgh coal bed data also allow estimation of the amount of original resource and the tonnage that remains. The results of this analysis are summarized by State in figure 7. Of an original 34 billion short tons, 16 billion short tons of resource remain. The data also clearly indicate that the best of the remaining resource is in southwestern Pennsylvania and adjacent areas of West Virginia (fig. 2), where blocks of medium ash ( $>8$ to $<15$ weight percent) and medium sulfur ( $>1$ to $<3$ weight percent) coal remain.

The remaining available, recoverable resource is less than 16 billion short tons. Various constraints on mining, including
Federal and State mining regulations, land use and environmental regulations and concerns, geologic and technical factors, and economic realities limit the amount of the coal resource that is actually available for production. Studies completed in various regions within the eastern coal fields indicate that the recoverable resources may be as small as 4 percent of the original in-place amount.
Figure 6. Generalized stratigraphic column of the Upper Pennsylvanian Monongahela Group. The Pittsburgh coal bed divides the Monongahela Group from the underlying Conemaugh Group strata in the Appalachian basin. From Tewalt, Ruppert, Bragg, Carlton, Brezinski, and Wallack, 1997.
Table 1. State averages of ash yield (percent), sulfur content (percent), and calorific value (British thermal units per pound) for the Pittsburgh coal bed on an as-received basis.

[Min = minimum; Max = maximum; Std. Dev. = standard deviation; No. Spls. = number of samples]

\begin{tabular}{|c|c|c|c|c|}
\hline State & & $\begin{array}{l}\text { Ash } \\
\text { yield }\end{array}$ & $\begin{array}{l}\text { Sulfur } \\
\text { content }\end{array}$ & $\begin{array}{c}\text { Calorific } \\
\text { value }\end{array}$ \\
\hline \multirow[t]{5}{*}{ Maryland } & Min & 5.7 & .7 & 12,870 \\
\hline & Max & 13.62 & 1.16 & 14,480 \\
\hline & Mean & 7.44 & .87 & 14,020 \\
\hline & Std. Dev. & 1.61 & .1 & 420 \\
\hline & No. Spls. & 33 & 32 & 21 \\
\hline \multirow[t]{5}{*}{ Pennsylvania } & Min & 1.85 & .47 & 10,780 \\
\hline & Max & 29.72 & 5.4 & 14,400 \\
\hline & Mean & 9.9 & 1.89 & 13,170 \\
\hline & Std. Dev. & 3.9 & .93 & 650 \\
\hline & No. Spls. & 578 & 564 & 503 \\
\hline \multirow[t]{5}{*}{ West Virginia } & Min & 3.9 & .4 & 11,190 \\
\hline & $\operatorname{Max}$ & 33.2 & 6.75 & 14,780 \\
\hline & Mean & 8.45 & 2.81 & 13,410 \\
\hline & Std. Dev. & 2.36 & 1.01 & 430 \\
\hline & No. Spls. & 1,968 & 1,964 & 1,689 \\
\hline \multirow[t]{5}{*}{ Ohio } & Min & 3.5 & .6 & 10,670 \\
\hline & Max & 24.1 & 6.41 & 13,740 \\
\hline & Mean & 9.97 & 3.48 & 12,380 \\
\hline & Std. Dev. & 2.91 & 1.04 & 610 \\
\hline & No. Spls. & 694 & 788 & 685 \\
\hline \multirow[t]{5}{*}{ All } & Min & 1.85 & .4 & 10,670 \\
\hline & $\operatorname{Max}$ & 33.2 & 6.75 & 14,780 \\
\hline & Mean & 9.02 & 2.8 & 13,130 \\
\hline & Std. Dev. & 2.9 & 1.13 & 680 \\
\hline & No. Spls. & 3,273 & 3,348 & 2,898 \\
\hline
\end{tabular}
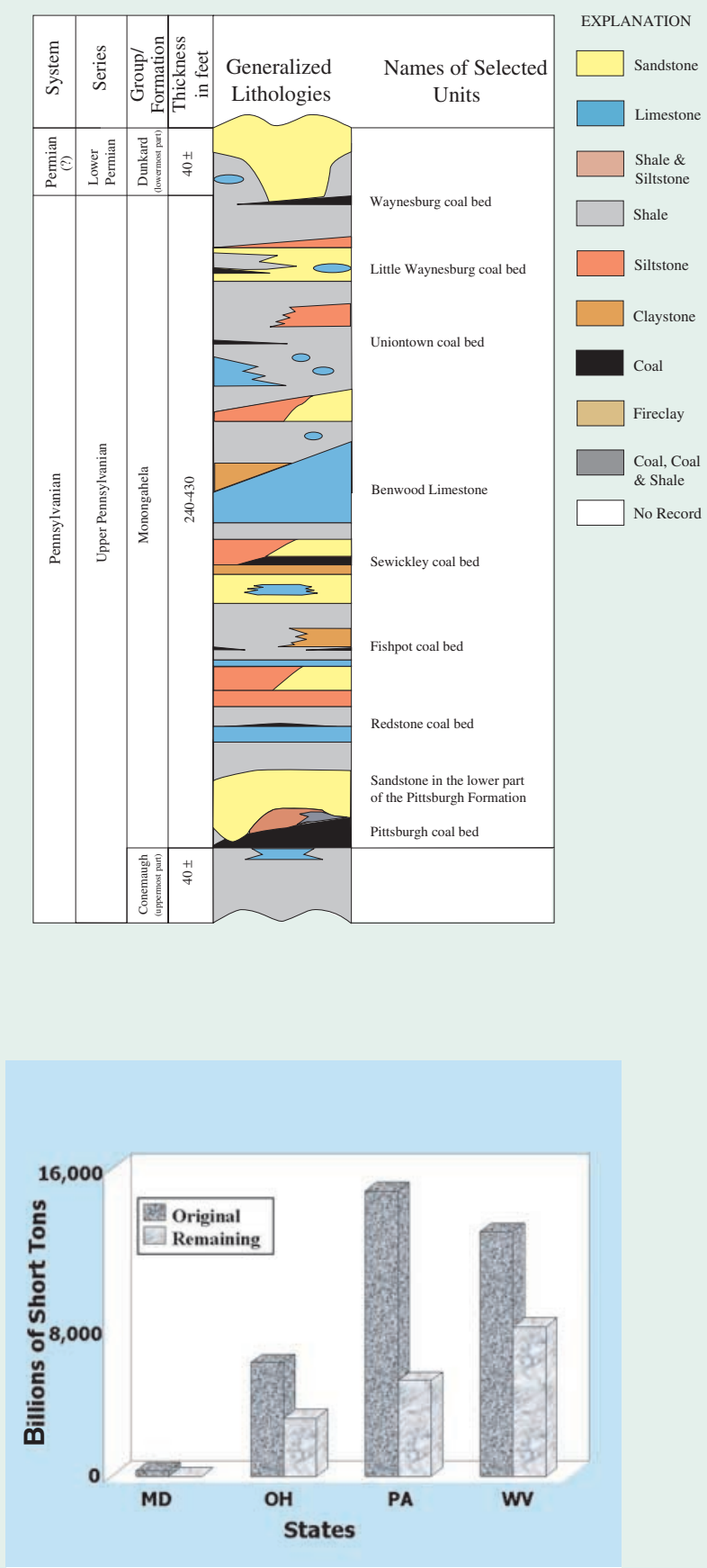

Figure 7. Original and remaining resources of the Pittsburgh coal bed in Maryland, Ohio, Pennsylvania, and West Virginia. 
(Continued from front page)

The CD-ROM will thus be a resource that provides a detailed, threedimensional picture of the form and character of each of the assessed coal beds and the non-coal-bearing strata or "horizons" that are laterally continuous with them. When combined with coal quality data (ash yield, sulfur content, trace elements), a remarkably detailed picture of the resource emerges. With GIS technology, this detail can be presented in a variety of ways to satisfy diverse needs.

\section{Sources of Information}

The primary sources of information for the assessment of coals in the northern and central Appalachian basin are two types of databases and an extensive archive of existing maps for each assessed coal bed.

1. Stratigraphic databases.-The stratigraphic databases contain descriptive information on coal beds compiled from tens of thousands of drill cores, surface outcrops, and mine and coal elevation records. Much of this information is stored in the NCRDS. Virtually all the records available contain data on coal bed thickness; many also include information on the occurrence of rock partings within the coal.

2. Geochemical databases.-The geochemical databases include data generated by the USGS, the former U.S. Bureau of Mines, The Pennsylvania State University, Federal and State agencies, and other published analyses. The databases consist of about 8,000 records containing ash yield, sulfur content, and gross calorific value for all samples and major-, minor-, and trace-element analyses (including antimony, arsenic, beryllium, cadmium, chromium, cobalt, lead, manganese, mercury, nickel, selenium, and uranium, depending on availability of information) for about 1,000 samples.

3. Map archive.-The map archive consists of more than 400 paper maps that the USGS has collected and digitized to establish the extent of coal beds and a variety of other records and sources that show the extent of areas already mined, both surface and subsurface. The maps are from the USGS, State Geological Surveys, commercial firms, and other published sources.

\section{Other Uses}

Coal resource information is useful for resource planning and development, and it has a number of other applications. Much of the coal in the Appalachian basin coal region has already been mined because it is high in calorific value and is easily removed. Remaining coals are generally higher in ash yield and sulfur content, stratigraphically deeper, and therefore, more expensive to mine. Many Appalachian coal mines have already closed, and others will be shutting down over the next couple of decades as they are mined-out and as new clean air standards are established. Appalachian coals are sometimes replaced by lower sulfur, economically competitive coals from the Western United States. These changes may cause severe economic disruption in communities that have been supported historically by coal. By using the assessment databases, it will be possible to identify these communities before the full effects of mine closings occur.

Maps can also be used as regional guides to pinpoint areas that may be vulnerable to other problems such as acid mine drainage. In the case of the Pittsburgh coal bed, for example, old mines are filling with water, creating a hydrostatic head that may drive acid waters into sensitive areas. By using the assessment areal extent, mining areas, and structure contour databases, potential avenues of drainage can be identified, and mitigation efforts put in place.

\section{References Cited}

Ruppert, L.F., Tewalt, S.J., and Bragg, L.J., 1997, Map showing areal extent of the Pittsburgh coal bed and horizon and mined areas of the Pittsburgh coal bed in Pennsylvania, Ohio, West Virginia, and Maryland, digitally compiled by Tully, J.K., Pierce, J., Weller, A., and Yarnell, J.M.: U.S. Geological Survey Open-File Report 96-280, scale 1:425,000. Available on the World Wide Web at http://energy.er.usgs.gov/products
Tewalt, S.J., Ruppert, L.F., Bragg, L.J., Carlton, R.W., Brezinski, D.K., and Wallack, R.N., 1997, Map showing generalized thickness contours of the Pittsburgh coal bed in Pennsylvania, Ohio, West Virginia, and Maryland, digitally compiled by Tewalt, S.J., Ruppert, L.F., Wallack, R.N., and Weiss, Eric: U.S. Geological Survey Open-File Report 97-748, scale 1:425,000, 1 sheet. Available on the World Wide Web at http://energy.er.usgs.gov/products

Tewalt, S.J., Ruppert, L.F., Bragg, L.J., Carlton, R.W., Brezinski, D.K., Yarnell, J.M., and Wallack, R.N., 1997, Map showing structure contours (sheet 1) and overburden isopleths (sheet 2) of the Pittsburgh coal bed in Pennsylvania, Ohio, West Virginia, and Maryland, digitally compiled by Tewalt, S.J., Wallack, R.N., and Tully, J.K.: U.S. Geological Survey Open-File 97-864, scale 1:425,000, 2 sheets. Available on the World Wide Web at http://energy.er.usgs.gov/products

For more information, please contact:

Leslie (Jingle) Ruppert

U.S. Geological Survey

956 National Center

Reston, VA 20192

Telephone: (703) 648-6431

E-mail: 1ruppert@usgs.gov 